\title{
The spatial effect of fiscal decentralisation on regional disparities: the case from Indonesia
}

\author{
Adiwan F. Aritenang
}

Received: 05032014 / Accepted: 19032014 / Published online: 30062014

(c) 2014 Faculty of Geography UGM and The Indonesian Geographers Association

\begin{abstract}
This study investigates the effect of decentralization on regional economic convergence between 1994 and 2004. Using spatial analysis, this research explains the presence of spatial dependence, which it is misleading to ignore it on the common linear regression. The paper argues that there is a strong evidence of spatial autocorrelation among Indonesia districts and regional convergence rate is higher in the decentralization period. Furthermore, the spatial error model suggested that, despite Jakarta's major economic and political role, a random shock is insignificant if it introduced to the capital city.
\end{abstract}

Keywords: Indonesia; Decentralization; Regional Convergence; Spatial Random Shocks

\begin{abstract}
Abstrak Studi ini mengkaji dampak otonomi daerah terhadap konvergensi ekonomi wilayah di Indonesia antara tahun 1994 dan 2004. Menggunakan teknik analisa spasial, penelitian ini menjelaskan adanya keterkaitan spasial. Studi menjelaskan bahwa terdapat keterkaitan spasial antara kota/kabupaten di Indonesia dan terdapat konvergensi wilayah setelah otonomi daerah. Selanjutnya, simulasi spasial menunjukkan bahwa random shock terhadap Jakarta tidak signifikan terhadap ekonomi di Indonesia.
\end{abstract}

Kata kunci: Indonesia; Otonomi Daerah; Konvergensi Wilayah; Spatial Random Shocks

\section{Introduction}

The neoclassical theory lies in the idea of dimin- ing empirical studies and literature on this subject. For ishing returns that implies a long run equalization of example, spatial econometrics analysis with in regional development. This theory seeks to explain the deter- convergence in the US [Rey and Montouri, 1999] and in minants of regional convergence rate with economic Turkey [Yildirim et al., 2009], and there are also studies growth is regarded as a growth of real terms of per on the spatial effect of trade liberalization such as by capita income and the variables are used to measure the Özyurt and Daumal [2013].

convergence of the economic growth rate, between ini-

While in Indonesia, there are non-spatial studies by tial level of output, y, and its target, $y^{*}$. Such variables Akita and Lukman [1995] and Resosudarmo \& Vidyatact as additional variables in the conditional conver- tama [2006]. The approach has also been implemented gence, while absolute convergence only examines the in Indonesia. For instance, a case study of income and initial level of output and the level of the target, without consumption in the capital city Jakarta, using the Local the effects of other variables. This theory has inspired Moran analysis shows the patterns in the core city of numerous studies of regional convergence with several Jakarta and found that the sub district of Tanah Abang approaches such as cross-section, time series, and panel has a negative association, i.e., a low value surrounded data analysis. by high values [Syabri, 2003]. The paper argues that the

Furthermore, there are also interests in studies the sub district is an urban decay as the conversion to busieffect of decentralization and trade liberalization on ness activity along with other rich sub districts in the intra-regional scale. The studies are varied in meth- core city of Jakarta has not taken place. Another case odology and geographical level of analysis with non- study of poverty analysis in East Java province by Pusspatial analysis such as Rivas [2007] that studies the pitasari, et al [2010] with a LISA cluster map illustrates impact of devolution and Rodríguez-Pose and Bwire that severe poverty cluster locations has moved from [2004] that examine the impact of trade liberalization south to the north and east part of the province beon Mexico regions. However, following the spatial au- tween 2003 to 2007. While the study by Karmaji [2010] tocorrelation at the regional scale theoretical studies by focuses on the agriculture location. Thus, there is lack Anselin [1988, 2007] and Arbia [2006], there is emerg- of spatial autocorrelation studies with regard on decentralization in Indonesia.

This paper aims to examine the presence of spatial autocorrelation in regional economic convergence 
in Indonesian decentralization. This research fills the research gap in the studies of regional development in Indonesia that presently neglected the role of spatial dimension. To do so, this paper follows previous studies that explore this effect using the statistics data and spatial econometrics analysis methods. There are two contribution of this paper. First, this paper analyses spatial autocorrelation at districts level to capture the dynamic of regional convergence in the decentralization period. Second, the paper examines the impact spatial sensitivity of Indonesia districts using a spatial shock.

This paper is arranged as follows; Section 2 discusses theories on decentralization and spatial econometrics. Section 3 presents an explanatory spatial analysis over the period 1994-2004. Section 4 elaborates spatial econometrics analysis. Section 5 concludes research findings.

\section{The Methods}

Despite this complex mathematical equation, the neoclassical theory is considered as a non-spatial convergence concept that has neglected that each region as a dependent entity and ignored the potential for interaction across space [Rey and Mountori, 1999]. The traditional concept views that the unit of analysis is individual regions observed as part of a cross section or time series. This stylized convergence analysis is contrast with the current development on economic geography. In the last decade, the economic geographic literature has recognized the relational concepts of regional developer. For instance, Krugman [1991] identified technology spillovers as the key mechanism that lead to convergence, has yet to be explored in the convergence stylized analysis. Similarly, other theories such as industrial districts and innovative milieu within the territorial innovation models also acknowledged the role of regional economic relationship and institutional arrangements. However, the emergence of spatial analysis provides a significant improvement in the regional convergence analysis that emphasis to understand the role of geographical proximity on regional economic growth.

The idea of spatial autocorrelation initiated from the geo-referenced map analysis that are not independent between each other. Despite the various concepts, such as distance-decay, spatial interaction, and spatial randomness, it cannot be associated with the concept of spatial autocorrelation. This is because spatial autocorrelation is linked with statistical theory than to spatial theory [Getis, 2007]. Thus, spatial autocorrelation theory evolved from the analysis of pattern of variables on maps. It was Luc Anselin [1988] that initiated spatial scientist including geographers, urban planner and economist to consider spatial effects in a geo-referenced models and data. Explanatory analysis of plausible and spatial-like clustering could explain a variety of situations such as revealing social interaction that are not seen in common display [Ward and Gleditsch, 2008]. Thus, these potentially unobserved clusters may influence our understanding on what is actually occurring. The presence of serial and spatial correlated observations, the classical tests is bias if the model interpretation accepting the hypothesized substantive account. In detail, it is assumed that data are spatially dependent that dependence is inversely proportionally to the distance between observations; $\rho$ refers the resultant first-order spatial correlation [Ward and Gleditsch, 2008]. This correlation measures the similarity between neighbors based on some attributes.

To apply these theories, several technical issues should be arise and concern. First, the substantive spatial dependence that concerns with the spatial relationship between regions refers to an economic development and growth of one region is determined by its neighbors. There are two types of spatial dependence which are global and local analysis. The global analysis assumes that regions have the same steady-state rate and the coefficient estimation is the average of the regions observed. This analysis has two methods which are spatial lag and spatial error models. The spatial error model observes spatial dependence that operates through the error process. The implication of this analysis is that as regions have the same steady-state, regions are therefore converging to the same long run growth path [Yildirim et al, 2009].

Second, there is also data organization mismatch issue between spatial boundaries and geographical administration. Literatures on the spatial econometrics shows that there has been a nuisance dependence that is reflected with the spatial auto correlated error term. Thus, the spatial error has two types, these are misspecification if both are ignored and second, spatial heterogeneity if a general instability of behavioral relationship across observation. The second type is assumed that there have identical rate of convergence across cross-section and is favored than time series. Thus, an analysis of convergence is not precluded.

Furthermore, Rey and Mountori [1999] with the SEM found that spatial autocorrelation of state per capita income in the US. This implies that while there is convergence, it is not spatially independent and there is movement of similar growth with its neighbors. Using AIC measurement, Yildirim et al [2009] shows the GWR model explain variations of per capita income in absolute and conditional convergence better than the global spatial analysis and OLS models. The GWR analysis allows the research to identify divergence of regional growth and found that government expenditure increases inequality between regions.

In respond to economic crisis 1997 and regions political and economic demands, Indonesia begins decentralization in 2001 in the form of devolution. Devolution is a global phenomenon with highly heterogeneous process following different political rationales [RodríguezPose and Gill, 2005]. Furthermore, decentralization has been regarded to promote regional disparity as effective and efficient administration leads to regional competi- 
tion [Islam, 1999]. The decentralization supporters argues that decentralization empower local government, which are more closely to its people, to have greater drive to practice better fiscal responsibilities and public service [Lin and Liu, 2000]. Another impact of decentralization is divergence of local institutional capacities.

The literature suggested that the decentralization regime enhances local authority controls over development through administration in public servants, budget, and policies. Further education and on-job-training are important to enhance local government bureaucrat capacities to generate policies and budget management. Thus, institutional capacities influence the rate of local development leading to larger gap between regions [Rodriguez-Pose and Gill, 2005]. Different institutional capacities and social endowments may undermine the potential to generate and implement policies that match local needs and public services [Rodriguez-Pose and Ezcurra, 2010; 2011]. Despite these wide possibility of decentralisation effect, for political and economic oppressed regions by the nation-state throughout the New Order regime, decentralization and devolution provides opportunity for regional development.

The decentralization in Indonesian has two law foundations, the Law 22/1999 and Law 25/1999. These two factors shape decentralization political and economic implementation [Asia Foundation, 2004]. The decentralization law no 22/1999 indicates three main shifts of political orders in the regions. First, the law shows reduction of central government power with devolving authority to sub-national and district levels, second it enhanced local council powers and third, although not as powerful as the local council, the law granted local government more authority to manage and develop its' regions. While the law no 25/1999 indicates two main issues, first it shows that there are fiscal agreements between central and regional governments regarding shared revenues. Second, the fiscal law enables the regions to borrow domestic and foreign funding, however the law do not mention which level of regional government and the limitation amount of funding that the regions are allowed to borrow. Specifically, fiscal decentralization establish two intergovernment transfer, the general purpose grant (DAU) and the special purpose grant $(D A K)$ the local government will manage their own the projects, although will monitored and evaluated by the central ministries.

Despite the presence of such law pillars, the de centralization of regional government in 1999 itself recently has been viewed to increased disparities, rather than reduce local development gaps. However, disparities have been acknowledged prior decentralization with studies that show severe disparities compared with other countries (Akita and Lukman, 1995; Garcia and Soelistianingsih, 1998). The following table shows that Indonesia local governments budget (Provincial and districts) still depends heavily on Central Government fund transfers (Table 1).
To promote a more balance regional development, the government has legalized the decentralization law 33/2004, which replace the decentralization Law 22/1999, that municipal/regency where the natural resources located, earn higher revenue share compared with the province government and other municipalities/regencies in the same province (Table 2). Hence, it is expected that with higher revenue share regions have more budget at its disposal for infrastructure and social development. However, studies shows that more taxing authority on a range of taxes and levies on regional governments to enhance regional revenue proportion from natural resources and income taxes [Brodjonegoro, 2003].

\section{Result and Discussion}

To explore regional disparities of Indonesia after the implementation of decentralization, statistic data between 1994 and 2004 are employed. In general, the data are gathered from the Central Bureau of Statistics (BPS). This paper uses aggregate data of regions before decentralization with 292 districts in 1997 , instead of post-decentralization where districts were divided for creation of new districts and swollen to more than 400 districts. However, this shortcoming is unavoidable due to data limitation for time series and panel data studies in Indonesia. Second, this study could be more improve with additional explanatory variables as founded in neo-classical growth theories such as human capital, health, and infrastructure.

This paper performs an absolute and conditional spatial regression analysis. Conditional spatial regression analysis interested with the effect of decentralization on regional convergence. The dependent variable is the GRDP per capita with the constant price year 2000. This paper approximates decentralization by using the two measurements of fiscal decentralization; the local revenue and intergovernmental transfer $(I G T)$.

This paper conducted several statistical analyses to explore Indonesia disparities, both non-spatial and spatial analysis. The first non-spatial analysis is Theil index, an entropy calculation that decomposed inequality index analysis from a higher spatial scale to lower level regions and also both between and within groups of regions [Canaleta et al., 2004; Yildirim et al., 2009]. This study considers hierarchical structure of inequality in Indonesia: region, provinces, and districts. The Theil inequality index:

$$
T=\sum_{i=1}^{n}\left(\frac{P_{i}}{P i d}\right) \mathrm{h}\left[\frac{P_{i}}{P_{i l}} / \frac{Y_{i}}{Y_{i d}}\right]=\sum_{i=1}^{n} p_{i} \mathrm{~h} t_{i}
$$

Where $\mathrm{P}$ is the total population, $\mathrm{Y}$ to income, while the subscript $i$ to region, id to Indonesia and $n=301$ for the number of province in this empirical analysis. Spatial effect analysis is also supported by advances in theory (social and spatial interaction) and technology (geographic information system, availability of spatial 
data, new spatial mathematical formulation, and new and powerful computers and software) [Anselin, 2007]. For example, various studies on the social science by Goodchild et al. [2000] and in political science by Franzese et al. [2009]. Another property of spatial analysis is the spatial weight matrix. Spatial weight matrix is a square matrix of dimension equal to the number of observations. The element wij refers to the weight matrix $\mathrm{W}$ is non-zero is locations $\mathrm{i}$ and $\mathrm{j}$ are neighbors, and zero otherwise (with the diagonal elements wij equals to zero). There are a wide range of criteria to define neighbors such as binary contiguity (common boundary), distance bands (locations within a given distance of each other) and "social" distance [Syabri, 2003]. The spatial weight matrix is used to represent the locational similarity and it is derived from the boundary files or coordinate data in a geo-referenced maps.

The Moran scatter plot is a specific scatter plot that visualized the degree of spatial autocorrelation, initiated by Anselin [1995]. The Moran scatter plot iscentered on the mean and shows the value of a variable $(\mathrm{z})$ on the horizontal axis and its spatial lag on the y axis (Wz or $\sum$ jwijzj) [Syabri, 2003]. The slope of the linear regression line through the scatter plot is the Moran's I coefficient (Wz on Z). In addition, a Moran scatter plot map that shows the locations that corresponds to the four quadrants. Thus, the software shows the degree of spatial autocorrelation in both cross-section and over time settings.

The Theil index indicates that overall disparities among regions in Indonesia has decline (Table 3). However, if we decomposed to three types of regional division, which are the within province, between province, and within province, the disparity level are diverse. The disparity among districts has decline sharply between the years, while the disparity between provinces has decline at a lower rate. An interesting finding is that disparities between three parts of Indonesia, the western, central and eastern region, increase significantly during the pre-decentralization period in the 1990s and peaked during the early 2000s before it reached its current position. This finding confirms that East region of Indonesia are severely left behind in economic and welfare terms.

Following Anselin [2003], the Moran scatter plot plots the standardized income per capita with its spatial lag in 1993 (Figure 1) and in 2006 (Figure 2). The four spatial quadrants represents four different types of spatial dependence between a district and its neighbors: The $\mathrm{HH}$ indicates districts with high income with high income neighbors (quadrant I-top left), a low income district with high income neighbors (quadrant II-top right), a low income district surround by low income neighbors (quadrant III-bottom right), and a high income district surround by low income neighbors (quadrant IV-bottom left). The quadrant I and III indicates positive forms of spatial dependence and the other two quadrants shows negative form. A different presentation of the spatial dependence is seen in the maps the local Moran statistics for each district at both years (Figure 3 and 4). Districts in Java Island and Papua are dominated with low income districts with higher income districts, which show negative spatial dependence among these regions. While districts in North and East Kalimantan have high income per capita districts, similar with their high income neighbors. While changes between 1993-2006 can be seen the most at Papua Island where it used to be almost negative spatial dependence with low income districts surrounded with higher income neighbors, in 2006 it become positive spatial dependence with a mix of high income districts surround by lower income districts.

Theory of SAL and SEM. The second non-spatial analysis is the $B$ Convergence and it is calculated to overview absolute convergence (less developed regions grow faster than rich regions) exists [Barro, 1991]. The regression equation for Absolute $B$ Convergence is as follow:

$T=\sum_{i=1}^{n}\left(\frac{P_{i}}{P i d}\right) \mathrm{h}\left[\frac{P_{i}}{P_{i l}} / \frac{Y_{i}}{Y_{i l}}\right]=\sum_{i=1}^{n} p_{i} \mathrm{~h} t_{i}$

Where the dependent variable is the logarithm of per capita income or product, $y$, and $B$ are constants, with $0<\beta<1$ and uit, is the random disturbance term. At $B>0$ implies that -convergence since the annual rate of growth is negatively related with $\ln (\mathrm{yi}, \mathrm{t})$, with higher value of $\beta$ shows convergence. Conditional convergence occurs (poorer regions grow faster than rich regions if other variables takes into accounts beside initial income level). For $\beta$ convergence conditional the empirical model is as suggested by Resosudarmo and Vidyattama [2006]:

$$
T=\sum_{i=1}^{n}\left(\frac{P_{i}}{P i d}\right) \mathrm{h}\left[\frac{P_{i}}{P_{\dot{~}}} / \frac{Y_{i}}{Y_{\dot{d}}}\right]=\sum_{i=1}^{n} p_{i} \mathrm{~h} t_{i}
$$

The regression in equation (3) is for the conditional convergence analysis with $\mathrm{i}$ is the administration level, provincial or district, this the index of time, yit is GDP per capita, the X'it are the vector of local revenue and $Z^{\prime}$ it is the intergovernmental transfer fund variable. The model needs the individual effect, ni, to capture all the determinants of growth for various regions in panel data analysis. The uit is the random disturbance not to be correlated when the time or region is not the same and assume uit is constant. The conditional convergence model has its basic on endogenous growth theory demonstrates that policy measures can have an impact on the long-run growth rate of an economy [Aghion and Howitt, 1998].

To performed spatial regression analysis, we construct spatial weight based on the distance based spatial matrix, rather than the adjacency matrix because the former model allow islands (contiguity), considering Indonesia's natural geographic islands. Considering Indonesia geographical character, the choice of the weight matrix type depends on the research location. For example, if the study focuses on one island, the appropriate weight matrix is the contiguity matrix, as it considers re- 
gions that share a common border are neighbors. While if the study involves several islands, the nearest neighbor weight matrix could be an option [Karmaji, 2010].

The Indonesia map is obtained from private mapping consultant with provincial and districts borders in the pre-decentralization with 26 provinces and 292 districts. Spatial regression requires Indonesia districts map to construct the spatial matrix using specific methods such as inverse matrix and k-nearest neighbor calculation.

$$
\begin{aligned}
& T=\sum_{i=1}^{n}\left(\frac{P_{i}}{P i d}\right) \mathrm{h}\left[\frac{P_{i}}{P_{i l}} / \frac{Y_{i}}{Y_{\dot{~}}}\right]=\sum_{i=1}^{n} p_{i} \mathrm{~h} t_{i} \\
& T=\sum_{i=1}^{n}\left(\frac{P_{i}}{P i d}\right) \mathrm{h}\left[\frac{P_{i}}{P_{i d}} / \frac{Y_{i}}{Y_{i d}}\right]=\sum_{i=1}^{n} p_{i} \mathrm{~h} t_{i}
\end{aligned}
$$

Based on the properties of spatial dependence, there are three types of spatial regression, the spatial lag and the spatial error) [Rey and Montouri, 1999]. The regression specification above measures the trade impact using spatial lag (equation 4) and spatial error model (5). With same variable specification as the non-spatial regression above, the spatial lag model adds the $\lambda$ as the coefficient for spatial lag (p), while $\zeta$ is the coefficient for the spatial error model (rho). While to study weather spatial convergence are in presence, this research follows Rey and Montouri [1999] that employs robust Moran's I and robust Lagrange Multiplier ( $L M)$ models. The significant of $\rho$-value of robust Moran's I provides strong evidence of spatial dependence and the strategy from Anselin [2003] that elaborates to decide either it's a spatial error and spatial lag type of spatial dependence. Another method is the maximum likelihood $(M L)$ for the spatial lag and spatial error models. Spatial lag model refers to lagging spatial area by including a serially autoregressive term of the dependent variable [Arbia, 2006]. This method answers how the growth in a region could relate to its neighbors and to what extend it influence. While the spatial error model illustrates the dependence through error process in which the errors from different provinces or districts may exhibit spatial covariance [Rey and Montouri, 1999]. The speed of convergence confirms the presence of convergence across time annually [Arbia, 2006]. The $\beta$ symbol refers to the coefficient of convergence and the $\mathrm{T}$ is the number of years under observation.

In addition, to choose the best fit regression model, it is common to use the Akaike information criterion $(A I C)$ and Bayesian information criterion $(B I C)$. The $A I C$ is compares the estimation values between $O L S$ and the spatial dependence model, and the preferable estimation is model with the lowest $A I C$ value. In addition, the criterion may also use the $B I C$ to solve over-fitting in maximum likelihood estimations, due to adding additional parameters, by introducing a penalty term for the number of parameters in the model. This penalty for additional parameters is stronger than that of the AIC.

In Table 4 , we present the result of unconditional convergence model of a cross-sectional regression for the Indonesia districts. To overview the period characteristics, we estimate models for the trend break in periods: 1994-2004, 1994-2001, and 2001-2004. The results show that the regressions from each period yielded highly significant and negative coefficients for the starting levels, confirming that convergence occurs for Indonesia districts. However, the post-decentralization period confirms a divergence regional growth marked with an insignificant coefficient. The long run convergence annual rate between 1994 and 2004 is very low at $0.6 \%$, compared with other findings elsewhere at about 1.9\% [Barro, 1991; Barro and Sala-I-Martin, 2004; Rey and Montouri, 1999]. This might indicate structural political and economic change of Asian economic crisis and decentralization between the years under observation.

The bottom part of Table 4 reports the diagnostics for the presence of spatial effects. Following Rey and Montouri [1999], this research uses three different tests: a Moran's I test and two Lagrange multiplier robust tests. The Moran's I test is used to test spatial dependence, the spatial lag and spatial error models, but it cannot be used to distinguish between both models. On the other hand, the robust tests suggest the presence of spatial error correlation rather than spatial lag.

The Table 5 reports the results on spatial dependence regression. The value of Akaike Information Criterion $(A I C)$ shows that each spatial model fits better than the unconditional models in Table 3. The AIC corrects the log likelihood function for over-fitting and the best fitting model is the one with the lowest value of AIC [Anselin, 2003; Rey and Montouri, 1999]. As found in other literatures in similar field, the spatial error model achieves best fits for each of the periods. This shows that the unconditional model suffered from mis specification due to the absence of spatial dependence. The coefficients for the spatial error and spatial lag are only significant for the early period, while not for the entire period and the last period. While similar results was also found in Rey and Montouri [1999] where spatial lag for initial income levels in the cross-regressive model is never significant. This diagnostic result reports that there is significant spatial dependence in the cross-regressive model. The last column describes the convergence rate with spatial dependence taken into account for the spatial error models. In each period, the convergence rate has slower rate than the unconditional model and as found in the unconditional model, the first period has higher convergence than the whole period. Furthermore, the spatial dependence model also indicates higher convergence rate in the post decentralization compared with the centralized regime.

The last table calculates the conditional spatial analysis for two proxies of fiscal decentralization (Table 6). The non-spatial regression shows significant conver- 
gence with the higher coefficient in the pre-decentralization period with at -0.117 (column 1 and 2). However, the analysis in the decentralization period lack of sig nificant determinant factors, as local revenue and intergovernmental transfer variables are insignificant. Thus, the analysis only explains 28.6 per cent of regional economic growth in the decentralization period. The following analysis confirms convergence regional growth when spatial dependence is included (column 3 and 4). Similar with the non-spatial OLS, the spatial dependence analysis shows that convergence rate is higher in the pre-decentralization than in the decentralization period, -0.116 and -0.07 , respectively. The analysis also suggested that both local revenue and intergovernmental transfer are spatially significant in the pre decentralization period. However, the analysis did not provide evidence of spatial autocorrelation as the spatial error is insignificant for both period.

The analysis is interested with the change of economic growth due to shock through the spatial error model. Following Rey and Montouri [1999], this article introduce a shock to the capital city, Jakarta, error term and substitute the maximum likelihood estimations of the spatial error model coefficients into equation (5) to estimate the degree of spatial spill-over. The shock is introduced to Jakarta as it is the largest and most economicconnected city in Indonesia, thus a shock is expected to significantly fluctuate the country's economy condition. This is illustrated with the following map that shows the further a region from Jakarta it does not necessarily to have lower change of economic growth (Figure 5). The shock effect on Jakarta is $37 \%$ lower relative to the estimate without the shock and it had the largest impact to the bordering South Kalimantan regency of Barito Kuala. This case of Indonesia does not confirm the findings of Rey and Montouri [1999] that found clear spatial pattern due to the shock for the case in USA. In detail, in Java itself, the shock does provide a spatial pattern with districts bordering with Jakarta had significant effect of economic growth.

\section{Conclusion}

In this paper, I have provided new insights to the regional economic convergence patterns in Indonesia between pre and post decentralization. This paper improves previous research by acknowledging the role of spatial effects in the formal analysis of regional convergence in general and specifies the spatial effects uniqueness of Indonesian main islands.

The exploratory methods conducted in this paper proofs strong evidence of spatial autocorrelation among Indonesia districts. While districts are converging in relative GRDP, there is evidence that this movement is similar to their neighbors. Thus, this study gives evi-

Table 1. Local Expenditure Proportion to Central Government Budget in Indonesia, 2002-2005 (\%)

\begin{tabular}{lrrrr}
\hline & $\mathbf{2 0 0 2}$ & $\mathbf{2 0 0 3}$ & $\mathbf{2 0 0 4}$ & $\mathbf{2 0 0 5}$ \\
Local Expenditure/ Central Expenditure & 47.19 & 37.73 & 42.34 & 41.93 \\
Local Expenditure/GDP & 7.07 & 4.93 & 7.82 & 8.6 \\
Local Development Budget / Central Development Budget & 19.36 & 10.02 & 14.25 & 5.22 \\
\hline
\end{tabular}

Source: BPS, Author's calculation

Table 2. Comparison Balance Fund: Level of transfer of fund between Central and Regional Governments under Law 25/1999 and its revised in 2004

\begin{tabular}{|c|c|c|c|c|c|c|}
\hline \multirow{2}{*}{$\begin{array}{l}\text { Revenue Source } \\
\text { Central Government } \\
\text { proportion }(\%)\end{array}$} & \multicolumn{3}{|c|}{ Law 25/1999 } & \multicolumn{3}{|c|}{ Revised Law 2002} \\
\hline & $\begin{array}{l}\text { Local } \\
\text { Government } \\
\text { proportion } \\
\text { within Prov- } \\
\text { ince (\%) }\end{array}$ & $\begin{array}{l}\text { Central } \\
\text { Government } \\
\text { proportion (\%) }\end{array}$ & $\begin{array}{l}\text { Provincial } \\
\text { Government } \\
(\%)\end{array}$ & $\begin{array}{l}\text { Municipal- } \\
\text { ity/Regency } \\
\text { Government } \\
(\%)\end{array}$ & $\begin{array}{l}\text { Other } \\
\text { Municipal- } \\
\text { ity/Regency } \\
\text { in the same } \\
\text { Province (\%) }\end{array}$ & $\begin{array}{l}\text { Central } \\
\text { Govern- } \\
\text { ment } \\
\text { proportion } \\
(\%)\end{array}$ \\
\hline Natural Resources & 20 & 80 & 20 & 16 & 32 & 32 \\
\hline Oil mining & 85 & 15 & 84.5 & 3.1 & 6.2 & 6.2 \\
\hline Gas & 70 & 30 & 69.5 & 6.1 & 12.2 & 12.2 \\
\hline Income Tax & 80 & 20 & 80 & 8 & 12 & - \\
\hline Company Tax & 100 & 0 & 100 & 0 & 0 & 0 \\
\hline Land and property tax & 10 & 90 & 10 & 16.2 & 64.8 & - \\
\hline $\begin{array}{l}\text { Acquisition of land and } \\
\text { building rights }\end{array}$ & 20 & 80 & 20 & 16 & 64 & - \\
\hline
\end{tabular}

Source: Brodjonegoro, 2003 
Indonesian Journal of Geography, Vol. 4־No.1, June 2014 : 1 - 11

Table 3. Rate of Theil Index

\begin{tabular}{lrrrrr}
\hline No & Year & Within Province & Between Province & Between Region & Total Theil Index \\
\hline 1 & 1994 & 0.0001755 & 0.004576 & 0.0026553 & 0.0074068 \\
2 & 1995 & 0.0002703 & 0.0043449 & 0.0027102 & 0.0073254 \\
3 & 1996 & 0.0002438 & 0.0040856 & 0.003167 & 0.0074964 \\
4 & 1997 & 0.0002261 & 0.0039251 & 0.0031608 & 0.007312 \\
5 & 1998 & 0.0002028 & 0.003877 & 0.0034098 & 0.0074896 \\
6 & 1999 & 0.0001819 & 0.0036156 & 0.0034021 & 0.0071996 \\
7 & 2000 & 0.0001346 & 0.0031223 & 0.0035515 & 0.0068084 \\
8 & 2001 & 0.0001 & 0.0026991 & 0.0036386 & 0.0064377 \\
9 & 2002 & 0.0001187 & 0.0029979 & 0.00366 & 0.0067766 \\
10 & 2003 & 0.0001725 & 0.0030579 & 0.0036337 & 0.0068641 \\
11 & 2004 & 0.000086 & 0.0025249 & 0.0034105 & 0.0060214 \\
\hline
\end{tabular}

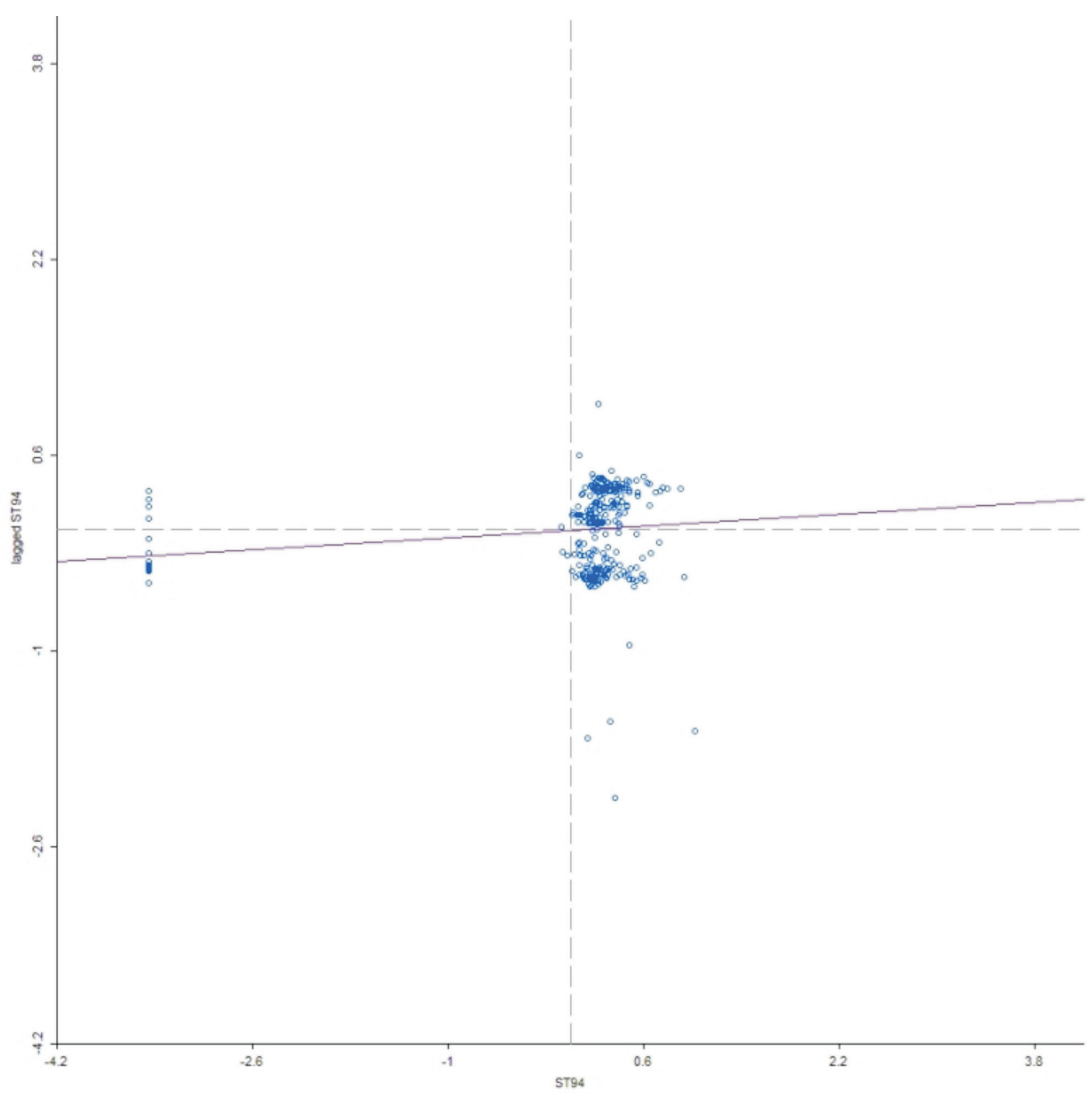

Figure 1. Moran Scatterplot districts per capita income, 1994 


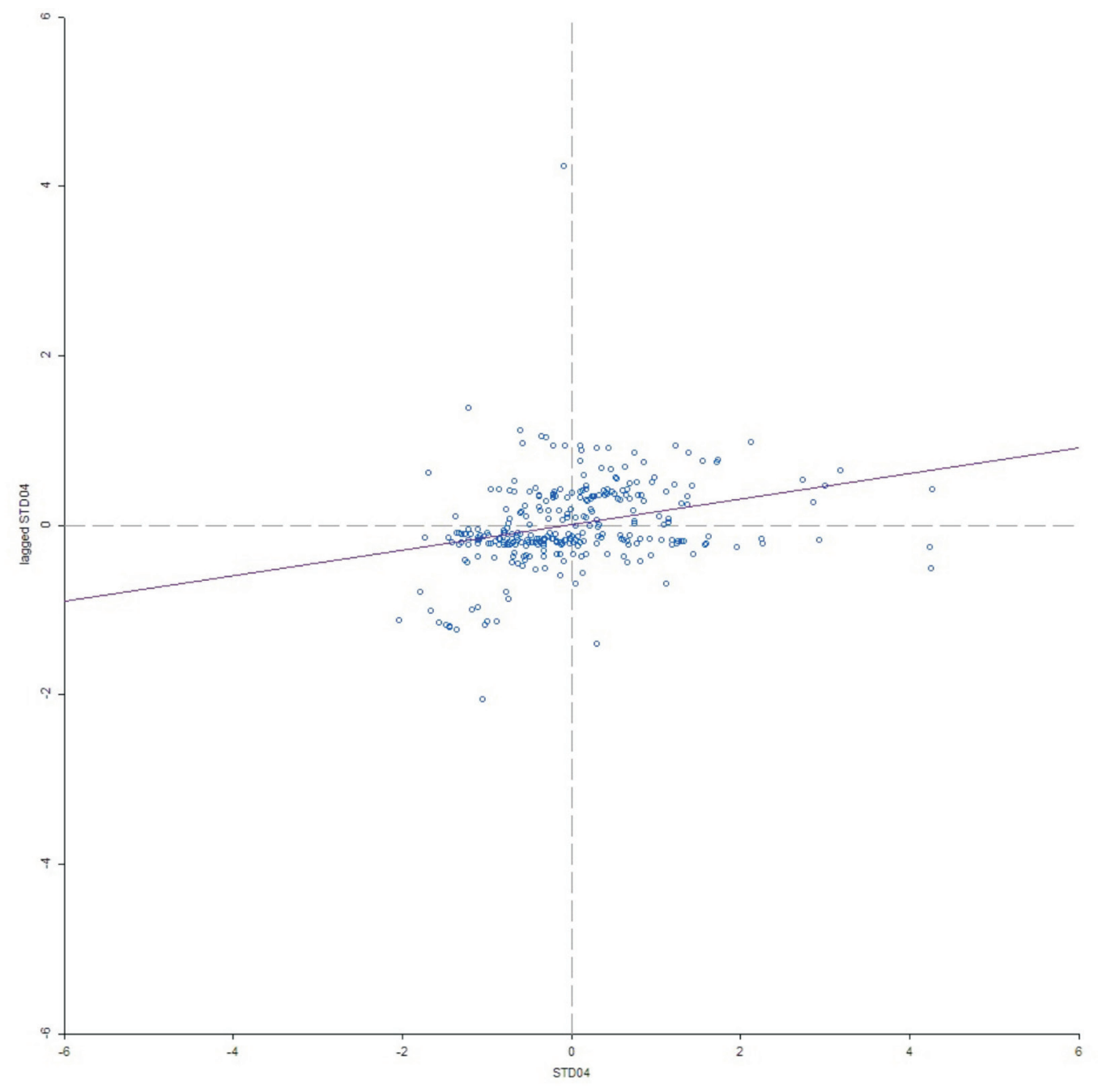

Figure 2. Moran Scatterplot districts per capita income, 2004

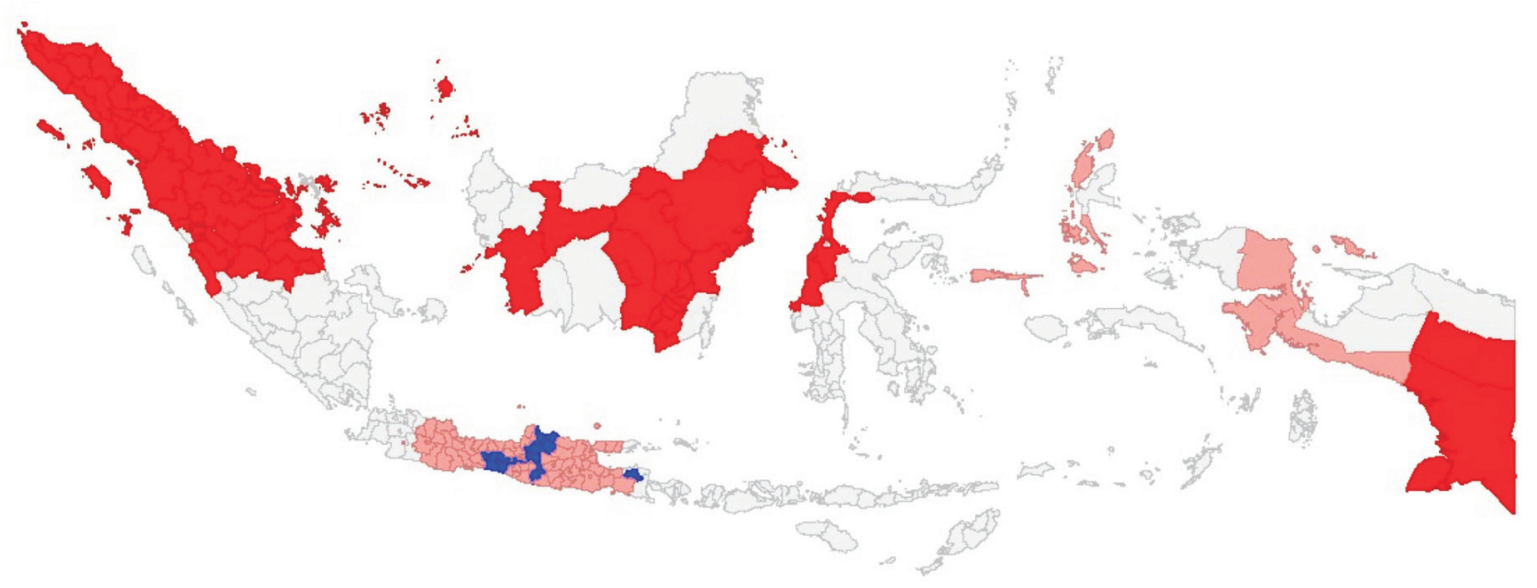

Figure 3. Local Moran statistics per capita Income, 1994 


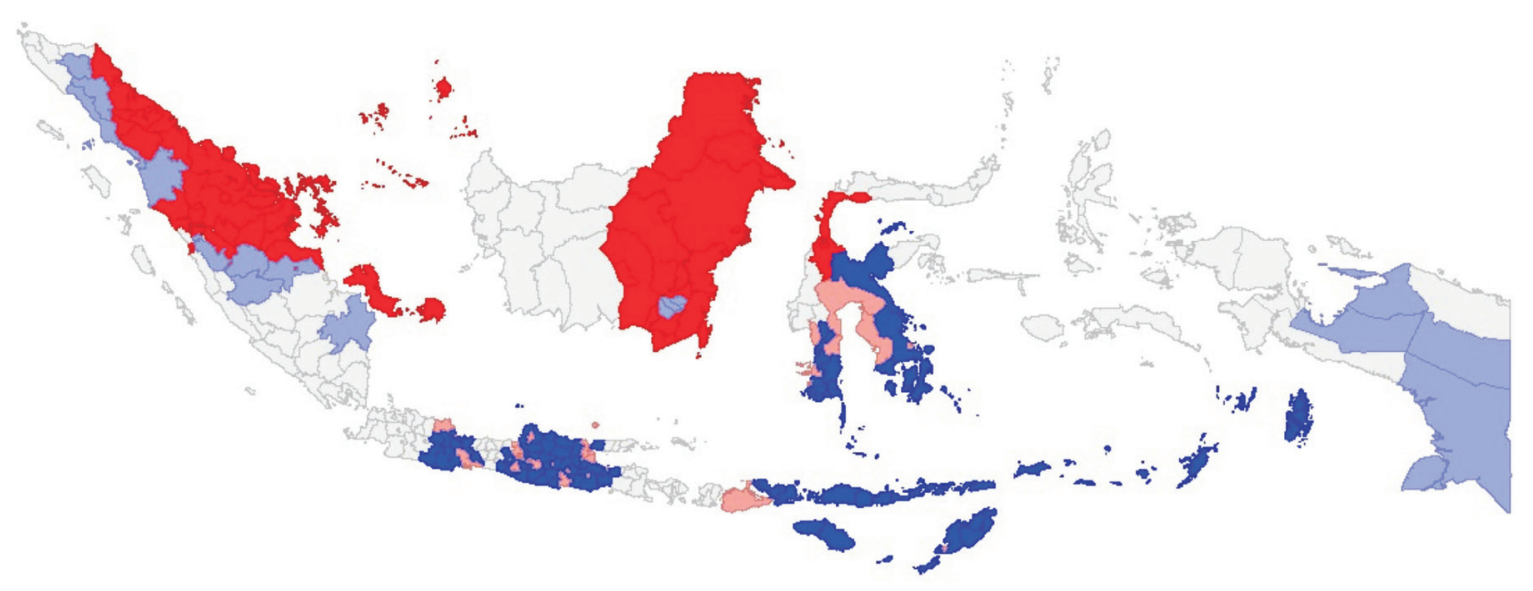

Figure 4. Local Moran statistics per capita Income, 2004

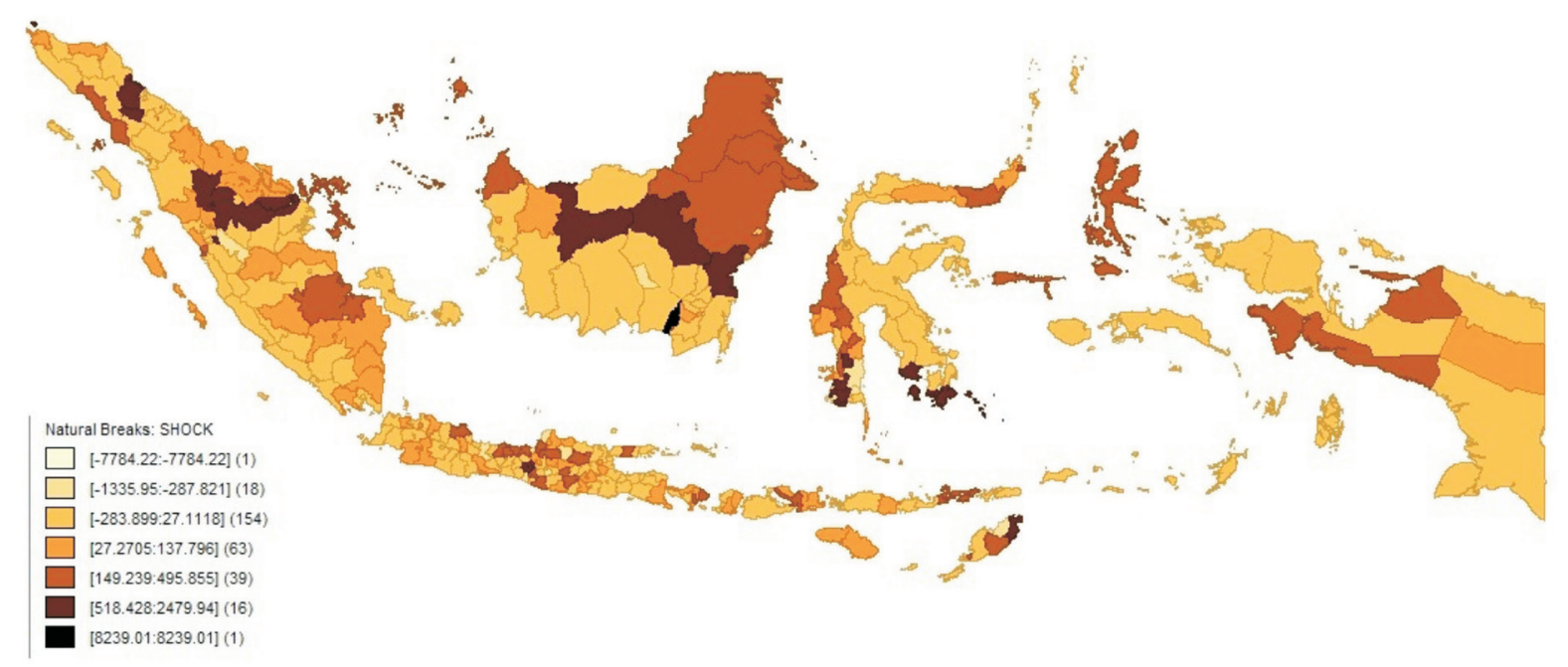

Figure 5. Percentage change in income growth due to spill-over shock to Jakarta, 2000-2004

Table 4.Unconditional model OLS Estimation

\begin{tabular}{lrrrrr}
\hline No & Year & $\mathbf{R}^{2}\left(\boldsymbol{\sigma}^{2}\right)$ & AIC & $\boldsymbol{\beta}$ (p-value) & Convergence Rate $(\boldsymbol{\theta})$ \\
\hline 1 & $1994-2004$ & $0.97(0.001)$ & -1093 & $-0.064(0.000)$ & 0.006 \\
\hline 2 & $1994-2000$ & $0.02(0.0003)$ & $-1518,8$ & $0.0007(0.006)$ & 0.00012 \\
\hline 3 & $2001-2004$ & $0.001(0.0003)$ & -1527.6 & $0.00065(0.51)$ & 0.00016 \\
\hline \hline No & Year & Robust LM (error) & Robust LM (Lag) & $\begin{array}{r}\text { Moran's I (error) } \\
\text { MI/p-value }\end{array}$ & $\begin{array}{r}\text { Breusch-Pagan test } \\
\mathbf{p} \text {-value }\end{array}$ \\
\hline 1 & & & 0.466 & $8.011 / 0.00$ & 0.000 \\
\hline 2 & $1994-2004$ & 0.000 & 0.024 & $1.705 / 0.088$ & 0.0002 \\
\hline 3 & $1994-2000$ & 0.048 & 0.533 & $2.47(0.013)$ & 0.005 \\
\hline
\end{tabular}


Table 5. Spatial Dependence models

\begin{tabular}{rlrrrr}
\hline No & & AIC & $\beta$ (p-value) & $\rho, \zeta$ (p-value) & $\begin{array}{r}\text { Convergence } \\
\text { Rate }(\boldsymbol{\theta})\end{array}$ \\
\hline & 1994-2004 & & & \\
1 & Spatial error (LM) & -1115 & $-0.06(0.000)$ & $0.443(0.0001)$ & 0.006 \\
2 & Spatial Lag (LM) & -1092.1 & $-0.06(0.000)$ & $0.01(0.67)$ & 0.006 \\
& & & & & -0.0000997 \\
1 & 1994-2000 & & & $0.244(0.09)$ & -0.00011 \\
\hline
\end{tabular}

Table 6. OLS Conditional Regressions

\begin{tabular}{|c|c|c|c|c|}
\hline & \multicolumn{2}{|c|}{ Non-spatial } & \multicolumn{2}{|c|}{ Spatial Dependence } \\
\hline & (1) & (2) & (3) & (4) \\
\hline & $1994-2000$ & 2001-2004 & $1994-2000$ & 2001-2004 \\
\hline Constant & $0.052(0.15)$ & $-0.09(0.09)$ & $-0.009(0.15)$ & $-0.009(0.09)$ \\
\hline$\beta$ Convergence & & & & \\
\hline (p-value) & $-0.117^{\star * \star}(0.009)$ & $-0.07^{* * *}(0.006)$ & $-0.116^{\star * *}(0.09)$ & $-0.07^{* * *}(0.006)$ \\
\hline Local Revenue & $-0.25^{\star * *}(0.07)$ & $0.018(0.021)$ & $0.238^{\star * \star}(0.07)$ & $0.019(0.02)$ \\
\hline $\begin{array}{l}\text { Intergovernmental } \\
\text { Transfer }\end{array}$ & $-0.179(0.09)$ & $-0.008(0.027)$ & $-0.205^{\star}(0.09)$ & $-0.009(0.02)$ \\
\hline Spatial Error $(\zeta)$ & & & $-0.186(0.18)$ & $-0.04(0.16)$ \\
\hline Adj R2 & 0.338 & 0.286 & 0.349 & 0.293 \\
\hline Obs & 292 & 292 & 292 & 292 \\
\hline
\end{tabular}

${ }^{\star},{ }^{\star *}$, and ${ }^{\star \star \star}$ are 10 per cent, 5 per cent, and 1 per cent significance, respectively. Standard errors are in brackets

dence that spatial effect contribute to regional disparities, thus it will be a misleading to ignore. The local Moran map shows lack of spatial effect in Indonesia main islands with slightly than 50 per cent districts has significant spatial autocorrelation with its neighbors. Second, there is evidence that convergence rate is higher in the decentralization period. This confirmatory analysis reveals that the a-spatial regression is mispecified as the evidence of spatial dependence is presence. The spatial error model also suggested that through random shocks individual districts are not only move from its current steady state, but also throughout the system of districts that influence dynamic of regional convergence.

The insignificant spatial shock suggested that a geographically-centered shock is not appropriate for an island country such as Indonesia. A shock should be introduced to individual islands and longer years of observation in the post decentralization period will provide more accurate analysis to examine the possible spatial dependence. However, this study should be considered as frontier for spatial dependence analysis on Indonesia regions. There are two policy implications from this research finding. First, decentralization law should be revised to reduce district disparities. For example, fiscal capacities should be transfer more significant to lowered fiscal dependency to the state [Lele, 2012] is crucial to improve local development. Second, further economic policy to enhance and accelerate districts economic growth in Java and Papua should be prioritized to promote balance development within the islands. Regional economic concepts could be applied to achieve this such as classical (regional growth centers such as agglomeration in industry clusters) and contemporary concepts (learning regions with improving local institutional capacities and local knowledge-based industries such as technology innovation and creative industry). Recent studies highlights regional development should acknowledge local variation and thus development strategies should be adjusted [Barca et al, 2011; Puspitasari, et al, 2010].

\section{Acknowledgement}

This may give an appreciation to institution or response that helps in research and report writing. This part may also describe the source of research fund use in the research. Parts of the paper was written during the author's PhD study at the University College London, which was funded by the Ministry of Communication and Information Technology, Republic Indonesia. 


\section{References}

Aghion, P., \& Howitt, P. (1998), Endogenous Growth Theory, MIT Press, Cambridge, MA.

Akita, T., \& Lukman, R. (1995), Inter-Inequalities in Indonesia: A Sectoral Decomposition Analysis for 1975-1992. Bulletin of Indonesian Economic Studies, 31(2): 61-81.

Anselin, L. (1988), Spatial Econometrics: Methods and Models. Kluwer, Dordrecht.

Anselin, L. (2003), Spatial externalities, spatial multipliers, and spatial econometrics, International Regional Science Review 26(2): 153-166.

Anselin, L. (2007), Spatial econometrics in RSUE: Retrospect and prospect, Regional Science and Urban Economics 37: 450-456.

Anselin, L., 1995, Local indicators of spatial association - LISA. Geographical Analysis, 27: 93-115

Anselin, L., Florax, R.J., \& Rey, S.J. (2004), Advances in Spatial Econometrics: Methodology, Tools and Applications 1st ed., Springer.

Arbia, G. (2006), Spatial Econometrics: Statistical Foundations and Applications to Regional Convergence 1st ed., Springer.

Asia Foundation. (2004), Decentralization and local governance in Indonesia, The Asia Foundation, Jakarta.

Barca, F., McCann, P., \& Rodríguez P. A. (2012), The Case for Regional Development Intervention: Place Based Versus Place Neutral Approaches. Journal of Regional Science 52(1): 134-152.

Barro, R.J. (1991), Economic Growth in a Cross Section of Countries, Quarterly Journal of Economics, 106(2): 407-443.

Barro, R.J., \& Sala-I-Martin, X. (2004), Economic Growth 2nd Ed., MIT Press

Brodjonegoro, B. (2003), The Indonesian Decentralization after law revision: Toward a better future?, Department of Economics, University of Indonesia.

Canaleta, C.G., Arzoz, P.P., \& Garate, M.R. (2004), Regional economic disparities and decentralization, Urban Studies 41(1): 71-95.

Franzese, R. J., Hayes, J.C., \& Kachi, A. (2010), “A Spatial Model Incorporating Dynamic, Endogenous Network Interdependence: A Political Science Application." Statistical Methodology 7(3): 406-428.

Garcia, J., \& Soelistianingsih, L. (1998), why do Differences in Provincial Incomes Persist in Indonesia?, Bulletin of Indonesian Economic Studies 34 (1): 95-120

Getis, A. (2007), Reflections on spatial autocorrelation, Regional Science and Urban Economics 37: 491-496

Goodchild, M.F., Anselin, L., Appelbaum, R., \& Harthorn, B. (2000), Toward spatially integrated social science. International Regional Science Review 23 (2): 139-159.

Islam, I. (1999), Regional Decentralization in Indonesia, towards a social Accord, Working paper 99/01.
United Nations Support Facility for Indonesia Recovery, Jakarta.

Karmaji, (2010), Analisis Spasial untuk Identifikasi Lokasi Pemusatan Potensi Pertanian, pp.125-140, dalam Reinvensi Pembangunan Ekonom Daerah, Penerbit Esensi

Krugman, P., (1991), Increasing Returns and Economic Geography, Journal of Political Economy, 99(3): 483-499

Lele, G. (2012), The Paradox of Distance in Decentralised Indonesia, Jurnal Ilmu Sosial dan Ilmu Politik 15 (3): 220-231.

Lin, J.Y., \& Liu, Z. (2000), Fiscal decentralization and economic growth in China, Economic Development and Cultural Change 49(1): 1-22.

Özyurt, S., \& Daumal, M. (2013), Trade openness and regional income spillovers in Brazil: A spatial econometric approach. Papers in Regional Science 92(1): 197-215.

Puspitasari, M., Nurmalasari, V., and Sjafii, A., (2010), Investigating the Economic Growth Impact on Poverty Reduction in East Java, in Regional Development in Indonesia (Priyarsono, D.S, and Ernan, R., Eds). Crestpent Press: Bogor, Indonesia

Resosudarmo B.P., \& Vidyattama (2006), Regional Income Disparity in Indonesia: A Panel Data Analysis, ASEAN Economic Bulletin 23(1): 31-44.

Rey, S.J., \& Montouri, B.D. (1999), US Regional Income Convergence: A spatial Econometric perspective, Regional Studies 33(2): 143-156.

Rivas, M.G. (2007), The effects of trade openness on regional inequality in Mexico, The Annals of Regional Science 41: 545-561.

Rodríguez-Pose, A. \& Gill, N. (2005), On the "economic dividend" of devolution. Regional Studies 39(4): 405-420.

Rodríguez-Pose, A., \& Bwire, A. (2004), The economic (in)efficiency of devolution. Environment and Planning 36(11): 1907 - 1928.

Rodríguez-Pose, A., \& Ezcurra, R. (2010), Does decentralization matter for regional disparities? A crosscountry analysis, Journal of Economic Geography 10 (5): 619-644.

Rodríguez-Pose, A., \& Ezcurra, R. (2011), Is fiscal decentralization harmful for economic growth? Evidence from OECD countries, Journal of Economic Geography 11(4): 619-643.

Syabri, I. (2003), Explanatory Spatial Data Analysis for Flow Data: Exploring the Error Term of Spatial Interaction Models, Jurnal Perencanaan Wilayah dan Kota 14(2): 49-68.

Ward. M.D., \& Gleditsch, K.S. (2008), Spatial Regression Models, Sage Publication, USA.

Yildirim, J., Ocal, N. \& Ozyildirim, S. (2009), Income Inequality and Economic Convergence in Turkey: A Spatial Effect Analysis, International Regional Science Review 32(2): 221-254. 